\title{
DRIVERS OF CUSTOMER SATISFACTION AND LOYALTY IN SERVICE INDUSTRIES
}

\author{
Hana Šuster ERJAVEC ${ }^{1}$, Tanja DMITROVIĆ ${ }^{2}$, Petra POVALEJ BRŽAN ${ }^{3}$ \\ ${ }^{1}$ Faculty of Business and Commercial Sciences, Lava 7, 3000 Celje, Slovenia \\ ${ }^{2}$ University of Ljubljana, Faculty of Economics, Kardeljeva pl. 17, \\ SI-1000 Ljubljana, Slovenia \\ ${ }^{3}$ University of Maribor, Faculty of Electrical Engineering and Computer Science, \\ Smetanova ulica 17, 2000 Maribor, Slovenia \\ E-mails: ${ }^{1}$ hana.erjavec@fkpv.si; ${ }^{2}$ tanja.dmitrovic@ef.uni-lj.si (correspondingauthor); \\ 33ptra.povalej@uni-mb.si
}

Received 13 October 2012; accepted 27 October 2013

\begin{abstract}
The relationship between customer satisfaction, customer loyalty and their antecedents, service output quality, quality of staff, corporate image, and price perception, is examined in the context of three service industries: use of the highway infrastructure, mobile telephone services, and hairdressing services. The research model was empirically evaluated for a large sample of respondents from a Central European country, using structural equation modelling. The results indicate that the four antecedents affect customer loyalty, and customer satisfaction acts as a mediator in all three service industries. However, the strength of the relationship between the constructs varies markedly across the industries, implying that competitive environment importantly determines the elements of service offering that lead to satisfaction and loyalty in a particular industry. The research findings contribute to a better understanding of which behavioural mechanisms and factors are a viable basis for increasing customer retention in a specific market structure. Managerial implications are discussed, and policy recommendations are offered.
\end{abstract}

Keywords: customer satisfaction, customer loyalty, service quality, price perception, corporate image, market structure.

JEL Classification: M31, M38.

\section{Introduction}

Customer satisfaction research has been one of the most prolific fields in marketing over the last 30 years. Marketing scholars have developed and validated a range of measurement instruments and models, where they established links between customer satisfaction, company performance, and their antecedents. One such model is the service-profit chain model (Heskett et al. 1997), which posits that profitability derives from customer loyalty and satisfaction which ensue from a customer's perception of quality and received value. However, links between service quality, satisfaction, and behavioural outcomes are neither linear nor straightforward. Quality improvements may 
not transform into higher customer satisfaction or higher profits (Rust et al. 1995), and high levels of satisfaction may not lead to loyalty or other positive forms of consumer behaviour. Furthermore, as demonstrated by the Jones and Sasser study (1995), the opposite relationship may hold: in markets characterised by a limited degree of competition, customers remain loyal no matter how dissatisfied they are.

The level of customer satisfaction can vary across different market structures (Rego 1998; Fornell 1995) thus it is relevant to establish whether a degree of competition in a particular industry affects the relationships between the constructs. We developed a satisfaction-loyalty model and evaluated it in three service industries with different market structure. Our research had two objectives: first, to develop a parsimonious measurement instrument and test whether that measurement can be applied to different services; and second, to investigate whether a degree of competition in an industry affects formation of customer satisfaction and loyalty.

Both objectives were motivated by theoretical as well as managerial considerations. We aimed to assess whether the proposed nomological network of customer satisfaction remains stable across markets with different levels of competition and then evaluate the strength of the relationships between the pre-determined constructs in dissimilar settings. Stability of a nomological network would imply that the measurement instrument can be universally applicable. However, the differences in the strength of relationships would indicate that results of satisfaction - loyalty research cannot be generalized across industries, and that competitive environment importantly determines the elements of service offering leading to satisfaction and loyalty in a particular industry. The latter analysis may be also valuable for assessing market efficiencies in the investigated industries and thus offer a new input for designing more effective public policy.

In the next section, we briefly outline the theoretical background and propose the research hypotheses. Based on the findings of preliminary qualitative research, we outline a final conceptual model and test it via structural equation modelling. Next, results and findings are discussed in terms of managerial and theoretical implications. The final section examines the limitations of the study and offers suggestions for future research.

\section{Literature review}

Customer satisfaction is central to the basic concept of marketing. It is defined as an emotional and cognitive evaluation of the customer's experience with a product or service and it represents the first step in loyalty formation (Oliver 1999).

\subsection{Antecedents to customer satisfaction and loyalty}

One of the most prominent drivers of satisfaction is service quality (Brady et al. 2002; Taylor, Baker 1994). Service quality perception is a summary judgment that is formed when the perceived service is compared with what was expected from it.

In defining service quality dimensions, we followed the Nordic school (Grönroos 1984; Lehtinen, Lehtinen 1991), and conceptualised the elements of quality in terms of three distinct constructs: (1) service output quality (a customer's perception of results received 
through interaction with the service provider); (2) quality of staff (the process of service delivery, and interactions between a supplier's representatives and the customer); and (3) corporate image (a company's corporate identity in the mind of the customer, which is not necessarily tied to the customer's experience).

Previous research confirms that service output quality positively affects customer satisfaction (e.g., Kristensen et al. 2000; Kristensen et al. 2001; Babin et al. 2005; Ekinci et al. 2008). In addition, service output quality has also a direct impact on loyalty. Kristensen et al. (2000) found that service output quality affects loyalty both directly and indirectly through satisfaction. Dabholkar et al. (2000) and Lee (2013) evaluated several competing quality-satisfaction-behavioural intention models and confirmed the mediating effect of customer satisfaction. Taylor and Baker (1994) showed that models that include an interaction of satisfaction and service output quality provide a better understanding of consumer purchase intentions than do those models that include only the main effects of service quality or satisfaction. Hence, we propose:

H1a: Service output quality has a positive impact on customer satisfaction.

H1b: Service output quality has a positive impact on customer loyalty.

In service industries, the process of service delivery is often even more important than the service itself, especially when customer involvement is high. Several surveys have found support for the quality of staff acting as an antecedent to customer satisfaction in various service industries (e.g., Bitner et al. 1990; Babin et al. 2005). Ekinci et al. (2008) found that, while both were significant, the quality of staff had a stronger impact on customer satisfaction than service quality.

Researchers have also explored the direct effects of quality of staff on customer loyalty. Kristensen et al. (2000) found that the quality of interactions with customers had a direct positive impact on loyalty and an indirect effect through customer satisfaction. Brady et al. (2005) compared several service evaluation models and found that the best performing model was one where service quality (operationalised as a service encounter construct) affected behavioural intentions both directly and indirectly through satisfaction. We therefore propose the following hypotheses:

H2a: Quality of staff has a positive impact on customer satisfaction.

H2b: Quality of staff has a positive impact on customer loyalty.

Corporate image refers to customer perceptions of a company as a whole and is in the mind of customers not necessarily tied directly to their experiences. Research has confirmed both direct and indirect effects (through satisfaction) of a corporate image on customer loyalty. For example, Martensen et al. (2000) showed that corporate image is the most important antecedent of customer satisfaction in eight service industries. Kristensen et al. (2000) identified corporate image as the most important antecedent to loyalty and the second strongest antecedent to customer satisfaction (after service output quality). On other hand, Ciavolino and Dahlgaard (2007) found corporate image to be a weaker predictor of customer loyalty than customer satisfaction and quality of services. A positive effect of corporate image on customer satisfaction was also confirmed in a 
survey of mobile telephone services users in Turkey (Türkyılmaz, Özkan 2007) and a direct positive effect on loyalty was found in the case of alpine ski resorts (Faullant et al. 2008). Based on these findings we propose:

H3a: Corporate image has a positive impact on customer satisfaction.

H3b: Corporate image has a positive impact on customer loyalty.

Anderson et al. (1994) noted that price is also an important antecedent of customer satisfaction, however, its impact on customer satisfaction has been less studied. Satisfaction with price is a very subjective perception. It is a ratio between benefits that the customer receives and the price he or she pays; therefore, it is necessary to compare price to a given standard (e.g., the price of competitive service, customer expectations, or the perceived value).

American Consumer Satisfaction Index (ACSI) shows that price-driven satisfaction is high in sectors where competition is relatively commodity-based. In these sectors, price plays a correspondingly important role. However, in service industries with high customer involvement and customized nature of products involved, price-driven satisfaction is low, implying that quality is relatively more central to market behaviours in these sectors (Fornell et al. 1996). Johnson et al. (2001) confirmed a significant effect of perceived price on satisfaction in four out of five studied service industries, and a direct impact of price on customer loyalty was supported in two industries. We posit:

H4a: Positive price perception has a positive impact on customer satisfaction.

H4b: Perceived price has a positive impact on loyalty.

\subsection{The customer satisfaction - loyalty relationship}

Satisfaction does not assure that customers will stay with a company (Jones, Sasser 1995). In fact, the relationship between customer satisfaction and customer loyalty was found to be the weakest link in Heskett et al.'s (1997) service-profit-chain model. Oliver (1999) suggests that satisfaction does not transform into loyalty as much as it is its precursor, which needs to be nurtured. Reicheld (1995) observed that many satisfied customers defect, implying that high satisfaction scores on satisfaction surveys do not translate necessarily into cash flows. To achieve long-term financial success, satisfaction must be transformed into loyalty; even more so in high-growth industries characterised by the cut-throat competition for market shares (Aksoy et al. 2013).

Notwithstanding the critiques outlined above, numerous empirical studies have confirmed a positive link between customer satisfaction and loyalty (e.g., Türkyılmaz, Özkan 2007; Faullant et al. 2008; Aksoy et al. 2013). The study by Kumar et al. (2013) indicates that in emerging economies, satisfaction is even more strongly linked to profitable customer loyalty than in developed economies. Based on this background, we propose:

H5: Customer satisfaction has a positive impact on customer loyalty. 


\subsection{The impact of market structure on customer satisfaction and loyalty}

The degree of market competition plays an important role in determining the relationship between customer satisfaction and loyalty. Jones and Sasser's (1995) research in the 1990's indicated that loyalty in highly monopolised industries (such as utilities or the airlines) might not be a consequence of satisfaction. Fornell (1995) postulated that dissatisfied customers will keep on buying from the same firm if no exit or switching is possible or if the alternatives available are just as dissatisfying. In such circumstances, customers are faced with a limited choice of service providers and hence virtually "forced" into loyalty. These factors can moderate satisfaction - loyalty link even in markets that do have several providers (Konuk F. A., Konuk F. 2013).

Anderson and Mittal (2000) point out that firms should consider the impact of competition on the satisfaction - loyalty link. In a recent study, Kumar et al. (2013) included market structure as one of the moderators in their framework for establishing "profitable customer loyalty". The concept refers to those customers who exhibit both behavioural and attitudinal loyalty and provide profits for the firm. It is contingent on several customer-specific, market-specific, and firm-specific variables that include past purchase behaviour, customer satisfaction, quality and price perceptions as well as competition. The authors propose that market structure variables affect customer loyalty behaviour. This is in line with results of Rego's (1998) research indicating a quadratic relationship between market concentration (as a measure of market structure) and customer satisfaction. Monopolies exhibit the smallest degree of customer satisfaction, followed by market structures with a low concentration level. Rego (1998) surmised that monopolies effectively lack the proper incentives to satisfy their almost captive demand, while in industries with highly fragmented and atomized competition, the marginal benefit of becoming more efficient or increasing customer satisfaction is negligible. In his research, customer satisfaction was the highest in the oligopolistic setting where an oscillating demand forced competitors to strive for achieving high levels of customer satisfaction to retain their market share. We thus postulate:

H6a: Market structure affects the level of customer satisfaction.

H6b: Market structure affects the level of customer loyalty.

\section{Empirical study}

An empirical test of these hypotheses was conducted on a large sample of adult consumers in a Central European country. We included three diverse types of services for evaluation: use of the highway infrastructure, mobile telephone services, and hairdressing services. These industries are characterised by different market structures. The highway infrastructure is a state monopoly, mobile telephony is a tight oligopoly (mobile phone services were at the time of data collection provided by six companies; one state owned), and hairdressing with its numerous small private providers corresponds to monopolistic competition. All three types of services are widely and frequently used by the general population. 
Prior to collecting survey data, we conducted a qualitative analysis using four focus groups. The results indicated that the initial conceptual model should be revised. None of the focus groups provided support for the impact of corporate image on loyalty, hence we dismissed hypothesis $\mathrm{H} 3 \mathrm{~b}$.

The final conceptual model is summarized in Figure 1. The model has six constructs: four antecedents (service output quality, quality of staff, corporate image, and perceived price), customer satisfaction as an intervening variable, and loyalty as the composite outcome variable. Degree of competition (as approximated by market structure) affects both customer satisfaction and customer loyalty.

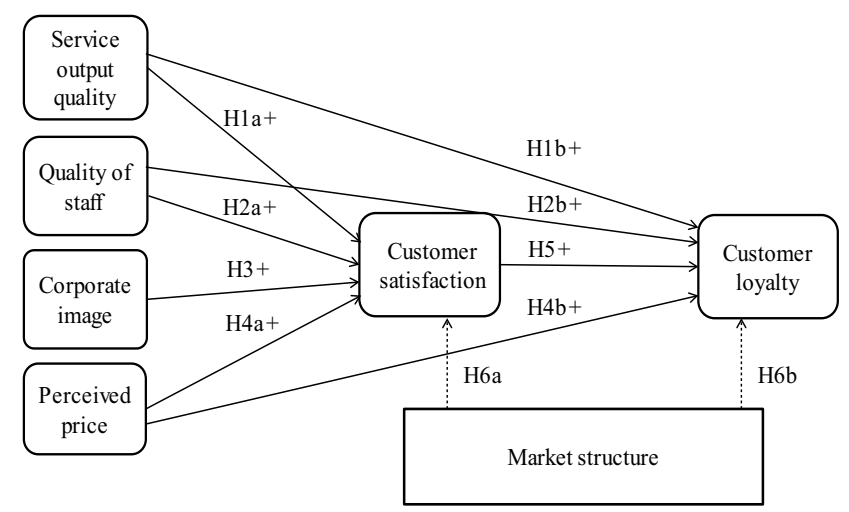

Fig. 1. The conceptual model

The concepts were operationalised based on the literature review and the findings of the focus group research (Table 1). Wherever possible, we adopted the scales used in national customer satisfaction indices (e.g., American - ACSI, European - ECSI, Swedish - NCSB) as their relevance has been supported in a large number of service industries and across different geographical settings. Degree of competition (market structure) was operationalised as a nominal variable that served as a group delineator in a multi-group SEM analysis.

Measurement scales were identical for all three industries. The advantages of this approach were threefold: it enabled the use of identical questionnaires in several service industries; it allowed for multi-industry comparisons; and it facilitated a generalization of findings. The instrument was parsimonious, as all the constructs contained three manifest variables. For all the items, a 10-item Likert-type scale was used (1-completely disagree; 10 - completely agree).

\subsection{Data collection and sample characteristics}

Data were collected via a web survey using the snowball sampling technique. Only respondents who had used all three types of services within the last three months were included in the survey. Each respondent was asked to evaluate all three types of services. This research design enabled a control for bias linked to personal characteristics of respondents and also facilitated the comparability of results. 
Table 1. Operationalisation of latent constructs

\begin{tabular}{|c|c|}
\hline Latent construct & Manifest variable \\
\hline $\begin{array}{l}\text { Service output } \\
\text { quality }\end{array}$ & $\begin{array}{l}\text { Overall service output quality. } \\
\text { Service output quality compared to expectations. } \\
\text { Service output quality compared to other companies. }\end{array}$ \\
\hline Quality of staff & $\begin{array}{l}\text { Overall quality of staff. } \\
\text { Quality of staff compared to expectations. } \\
\text { Quality of staff compared to other companies. }\end{array}$ \\
\hline Corporate image & $\begin{array}{l}\text { Overall corporate image. } \\
\text { Positive public image. } \\
\text { Ethical behaviour of the company. }\end{array}$ \\
\hline Perceived price & $\begin{array}{l}\text { Price compared to expectations. } \\
\text { Price compared to other companies. } \\
\text { Price compared to quality. }\end{array}$ \\
\hline $\begin{array}{l}\text { Customer } \\
\text { satisfaction }\end{array}$ & $\begin{array}{l}\text { Overall customer satisfaction. } \\
\text { Satisfaction compared to customer's "ideal" service provider in the category. } \\
\text { Performance exceeds expectations. }\end{array}$ \\
\hline Customer loyalty & $\begin{array}{l}\text { Re-purchase intentions. } \\
\text { Positive word of mouth. } \\
\text { Recommendation of this provider to others. }\end{array}$ \\
\hline Market structure & $\begin{array}{l}\text { Highways = state monopoly. } \\
\text { Mobile telephones = oligopoly. } \\
\text { Hairdressing = monopolistic competition. }\end{array}$ \\
\hline
\end{tabular}

Respondents were instructed to evaluate their premier service providers in each industry (i.e., the provider that contracts most of their business). The case of highway services was specific, as the highway system operates as a monopoly. To use the highway system, a driver is required to purchase a toll sticker (valid from 1 week up to 1 year). Competition in this industry is only indirect - if the customer decides not to pay the fee, he or she is forced to use alternative roads. In the other two industries, services could be bought from several providers that offer differentiated service products and employ a variety of pricing schemes.

The sample included 1154 respondents of which 67\% were women. A higher proportion of women respondents were logically expected, as many men do not visit hairdressers regularly. There was no missing data, as the questionnaire was designed so that all answers were required.

\subsection{Analysis and results}

Data were analysed using SEM analysis. First we tested the measurement model, followed by a structural model analysis, as suggested by Anderson and Gerbing (1988). To test the effect of market structure on the relationships between the constructs, we employed a multi-group analysis. 


\subsubsection{Measurement and structural model for aggregate data}

To assess model fit, we applied the Maximum Likelihood method. First, exploratory factor analysis was run for individual industries. Cronbach alpha and construct reliability $\Omega$ were calculated for all latent constructs. All coefficients were above 0.8 , except for loyalty to highway service provider $(\alpha=0.63 ; \Omega=0.69)$.

Convergent validity was supported, given that all the t-test values of indicator loadings for all the reflective constructs were statistically significant (Anderson, Gerbing 1988). Discriminant validity was tested by applying a $\chi 2$ test between pairs of latent variables (Anderson, Gerbing 1988), and was also supported.

Confirmatory factor analysis was first performed separately for each industry, and then the model was run on the entire sample. The adequacy of the measurement model on the aggregate data was established $(\mathrm{NFI}=0.951, \mathrm{CFI}=0.956, \mathrm{GFI}=0.901, \mathrm{IFI}=0.956$, RMSEA $=0.048$ ).

The structural model (run on the aggregate data) included four exogenous constructs (service output quality, quality of staff, corporate image, and perceived price) and two endogenous constructs (customer satisfaction and customer loyalty). Model fit indicators revealed adequate conformance of the data to the model $(\mathrm{NFI}=0.959, \mathrm{CFI}=0.960$; IFI $=0.960$, RMSEA $=0.072$ ). Results of this model testing are presented in Table 2.

Table 2. Results of structural model testing for the aggregate sample

\begin{tabular}{|c|c|c|c|}
\hline Hypothesis & Path & \multicolumn{2}{|c|}{ Standardised regression weight $\mathrm{t}$-value } \\
\hline \multicolumn{4}{|c|}{ Customer satisfaction drivers* } \\
\hline $\mathrm{H} 1 \mathrm{a}+$ & Service output quality $=>$ customer satisfaction & 0.57 & 33.47 \\
\hline $\mathrm{H} 2 \mathrm{a}+$ & Quality of staff $=>$ customer satisfaction & 0.29 & 20.47 \\
\hline $\mathrm{H} 3+$ & Corporate image $=>$ customer satisfaction & 0.08 & 14.97 \\
\hline $\mathrm{H} 4 \mathrm{a}+$ & Perceived price $=>$ customer satisfaction & 0.08 & 8.86 \\
\hline \multicolumn{4}{|c|}{ Customer loyalty drivers* } \\
\hline $\mathrm{H} 1 \mathrm{~b}+$ & Service output quality $\Rightarrow>$ customer loyalty & 0.36 & 11.76 \\
\hline $\mathrm{H} 2 \mathrm{~b}+$ & Quality of staff $=>$ customer loyalty & 0.20 & 9.08 \\
\hline $\mathrm{H} 4 \mathrm{~b}+$ & Perceived price $=>$ customer loyalty & 0.18 & 14.97 \\
\hline $\mathrm{H} 5+$ & Customer satisfaction $=>$ customer loyalty & 0.27 & 14.97 \\
\hline
\end{tabular}

An analysis of the aggregate data suggests that the strongest driver of customer satisfaction is service output quality followed by quality of staff. The impact of corporate image and perceived price on customer satisfaction is relatively weak. Together the antecedent constructs explained $96.5 \%$ of the variability in customer satisfaction.

Service output quality is also the strongest driver of customer loyalty. As hypothesised, customer satisfaction, the quality of staff, and perceived price were also significant predictors of loyalty. Customer satisfaction and exogenous variables explained $86.5 \%$ of the variability in customer loyalty. All paths in the model were significant, and signs of the effects were consistent with hypotheses H1-H5. 


\subsubsection{Multi-group analysis}

To test the impact of market structure on the relationships between these constructs, we performed a multi-group analysis. The multi-group model fit measures indicated good conformance of the data with the models $(\mathrm{NFI}=0.944, \mathrm{CFI}=0.950$; IFI $=0.950$, RMSEA $=0.050$ ).

The structure of the model was supported for all market structures; however the strength of relationships between the constructs differed between the industries. Table 3 shows the standardised regression weights and proportion of explained variance for endogenous constructs for all three industries. These results suggest that customer attitudes toward service output quality, quality of staff, corporate image and perceived price vary across industries.

Table 3. Results of multi-group structural model testing per industry

\begin{tabular}{|c|c|c|c|c|}
\hline Hypothesis & Path & Highways & Mobile telephones & Hairdressing \\
\hline \multicolumn{5}{|c|}{ Customer satisfaction drivers* } \\
\hline $\mathrm{H} 1 \mathrm{a}+$ & $\begin{array}{l}\text { Service output quality }=>\text { customer } \\
\text { satisfaction }\end{array}$ & 0.55 & 0.48 & 0.18 \\
\hline $\mathrm{H} 2 \mathrm{a}+$ & Quality of staff $=>$ customer satisfaction & 0.39 & 0.19 & 0.66 \\
\hline $\mathrm{H} 3+$ & $\begin{array}{l}\text { Corporate image }=>\text { customer } \\
\text { satisfaction }\end{array}$ & 0.06 & 0.17 & 0.08 \\
\hline \multirow[t]{2}{*}{$\mathrm{H} 4 \mathrm{a}+$} & Perceived price $=>$ customer satisfaction & 0.04 & 0.23 & 0.11 \\
\hline & Customer loyalty drivers* & & & \\
\hline $\mathrm{H} 1 \mathrm{~b}+$ & $\begin{array}{l}\text { Service output quality }=>\text { customer } \\
\text { loyalty }\end{array}$ & 0.36 & 0.34 & n.s. \\
\hline $\mathrm{H} 2 \mathrm{~b}+$ & Quality of staff $=>$ customer loyalty & 0.25 & 0.11 & 0.62 \\
\hline $\mathrm{H} 4 \mathrm{~b}+$ & Perceived price $=>$ customer loyalty & 0.20 & 0.26 & 0.12 \\
\hline $\mathrm{H} 5+$ & $\begin{array}{l}\text { Customer satisfaction }=>\text { customer } \\
\text { loyalty }\end{array}$ & 0.18 & 0.26 & 0.11 \\
\hline \multicolumn{5}{|c|}{ Proportion of variance explained } \\
\hline & R2: Customer satisfaction & $94.9 \%$ & $90.9 \%$ & $94.9 \%$ \\
\hline & R2: Customer loyalty & $81.1 \%$ & $79.5 \%$ & $82.1 \%$ \\
\hline
\end{tabular}

Notes: * standardised regression weights. n.s. - not significant at the 0.05 level.

In the provision of highway services, the strongest driver of both customer satisfaction and customer loyalty was service output quality, followed by quality of the staff. In mobile telephone services, service output quality was a dominant factor contributing to customer satisfaction and loyalty. The second strongest antecedent was perceived price, followed by quality of staff. A completely different pattern emerged in hairdressing services. By far, the strongest driver of both satisfaction and loyalty was quality of staff. The impact of service output quality, corporate image, and perceived price was much weaker. In addition, the effect of service output quality on customer loyalty was totally 
mediated by customer satisfaction. The reason for that result may lie in the high correlation between both service quality constructs in this industry $(r=0.91)$. It implies that, in the eyes of consumers, quality of staff and quality of output are very closely related. To evaluate the hypotheses H6a and H6b, we used a series of paired-sample T-tests. The levels of customer satisfaction (H6a) and loyalty (H6b) were indeed different across industries; a more competitive market structure implied higher customer satisfaction and higher customer loyalty.

All hypotheses were supported, with an exception of effect of service output quality on customer loyalty (H1b) which was significant in two out of three industries and had thus only a partial support.

\section{Discussion and implications}

\subsection{Discussion}

While our model conceptualisation was largely supported, the main drivers of satisfaction and loyalty in all three types of services studied seem to be quite different. This result is consistent with the findings of previous research. For example, when comparing the results of ECSI for eight industries, Martensen et al. (2000) found that the actual pattern of influence depended on a particular industry setting.

The differences in the strength of the relationships found between the constructs across industries could be explained by differences in the levels of market competition and the differences in the types of ties between customers and service providers. Our research lent no support to Rego's (1998) conjecture that customer satisfaction will be the highest in an oligopoly setting. The highway service industry received the lowest satisfaction scores, while hairdressing achieved the highest scores, and mobile telephone services scores lay in the middle.

A possible explanation for this result rests in the nature of the ties between customers and suppliers. In use of a highway infrastructure, customers cannot choose between different alternatives; rather, they can only opt to use the highways or not use them.

Their decision "to buy" depends on the quality of service output, determined by such elements as length of the highway network, the quality of the road surface, amenities available in rest zones, a lack of traffic congestion and road obstructions, etc. Price perception does not importantly affect customer satisfaction with this service, but, according to findings of our qualitative research, it is factored into their (re)purchase decision. Despite an expressed dissatisfaction with highway services, loyalty remains high, indicating that customers are in effect being held »hostages« (Jones, Sasser 1995) in this service industry.

On the contrary, high satisfaction scores leading to a "true" long-term loyalty were achieved in the hairdressing industry. The predominant influence of quality of staff on customer satisfaction and loyalty can be explained by its relationship nature. In this industry, many customers do forge a personal bond with their hairdressers and in some cases will stay loyal to them for decades. A high degree of customization and personalization of hairdressing services places a high value on the relationship between the customer and the front-line service provider (hairdresser). 
The only industry in our sample that uses contractual relationship as an important marketing element is mobile telephone services. Providers of mobile telephone services are quite successful in establishing long-term contracts with their customers by offering them incentives (e.g. subsidised phone sets, discounted rates, etc.). Such contracts increase the switching costs for consumers. Customers with high switching costs are more loyal, but this loyalty can be characterised as "false" loyalty. Survey results suggest that consumers offset the risk of accepting a long-term contract by demanding significant price concessions from their mobile telephone service providers. This may be the reason for higher importance of price perception in this industry.

\subsection{Theoretical and managerial implications}

Our research model performs satisfactorily when applied to very different service settings thus the objective of developing a parsimonious, yet universal, measurement instrument was met. The results indicate that customer satisfaction plays an important role in establishing the relationship between quality perceptions and customer loyalty. Corporate image is not a particularly strong driver of customer satisfaction and ensuing loyalty. In this respect, our results differed from those offered by Martensen et al. (2000). Perceived price acts as an antecedent to customer loyalty, and its effect is partially mediated by customer satisfaction. It is interesting to note that the direct effect of perceived price on customer loyalty is much stronger than its impact on customer satisfaction, which supports the concern already voiced by several researchers that companies should pay more attention to measuring customer loyalty than just focusing on achieving customer satisfaction (e.g., Rust et al. 1995; Oliver 1999; Reicheld 1995; Anderson, Mittal 2000; Aksoy et al. 2013).

Our second objective was to investigate whether customer satisfaction and loyalty differ across industries with different market structures. Zeithaml (2000) suggests that understanding the relationship between constructs in service quality - loyalty framework is important, but it is perhaps more useful managerially to identify the specific drivers that most closely relate to the dependent and intervening variables. Our results suggest that the drivers of satisfaction and customer loyalty are markedly different in specific industries. Thus, managers must understand which elements of their service offerings lead to customer loyalty and then focus and direct their managerial efforts and investments accordingly. While cross-industry benchmarking may constitute an important source of ideas for developing new service offerings, simply transposing key success factors from other industries to their own business might not suffice. For example, our research shows that in the relational services, such as hairdressing, employees are the greatest asset, unlike the mobile telephone business where it is more crucial to find the appropriate ratio between the quality of service outputs and price. In monopolised industries, such as highway service provision, loyalty is high, despite general consumer dissatisfaction, but there is a limit to such a forced loyalty. In the absence of other supply alternatives, when quality - price discrepancies become too high, consumers simply choose to exit from the market.

These findings are relevant not only for designing more appropriate marketing strategies, but also for public policy. As proposed by Fornell (1995), customer satisfaction scores can serve as a proxy for market efficiency and can, as such, aid regulators in 
their assessment of social welfare in a particular industry. Survey results show that satisfaction scores increase as market concentration decreases, suggesting that competition promotes market efficiency. Hence, a small number of providers in an individual industry seem to be detrimental to consumer welfare. Public policy should thus introduce specific measures to mitigate the negative effects of imposing high entry barriers (such as high switching costs) and also limit the extent of market power in highly concentrated markets.

\section{Conclusions}

In our research we designed and tested conceptual model for measuring drivers of service satisfaction and loyalty in various service industries. We also investigated whether a degree of competition in an industry affects formation of customer satisfaction and loyalty. The results support the model: service output quality, quality of staff, corporate image, and price perception affect customer loyalty, customer satisfaction acts as a mediator in all three service industries, while competitive environment moderates the relationship between the constructs. The divergence in regression coefficients across different industries suggests that the strength of the links between the constructs varies across different service settings. To better understand the reasons for this variation, research in other markets would be clearly welcome. Also, further moderators, such as brand equity and switching costs, should be explored.

Our research has also some limitations. Survey design, which demanded that each respondent evaluates three types of services, had certain advantages, but it also had drawbacks. Even though our objective was to test the research model in a variety of service settings, we had to limit the number of investigated industries to only three. Inclusion of additional industries would have substantially lengthened the questionnaire and thus, impede the reliability and validity of the measurement. The quest for universality of a questionnaire produced another limitation: to apply the questionnaire to different services, the items had to remain very general, so particular features specific to an individual industry could not be observed. While our conceptual model built on the theoretical background, fine-tuning relied on the results of qualitative research. Consequently, the direct link between corporate image and loyalty was omitted from our empirical validation. However, it is possible that reported attitude was a result of social desirability bias, as it is reasonable to expect that participants would not like to admit that their behaviours are guided by marketers' persuasion tactics. This issue warrants further and more precise and focused exploration.

\section{References}

Aksoy, L.; Buoye, A.; Aksoy, P.; Larivière, B.; Keiningham, T. L. 2013. A cross-national investigation of the satisfaction and loyalty linkage for mobile telecommunications services across eight countries, Journal of Interactive Marketing 27(1): 74-82.

http://dx.doi.org/10.1016/j.intmar.2012.09.003

Anderson, E. W.; Fornell, C.; Lehmann, D. R. 1994. Customer satisfaction, market share and profitability: findings from Sweden, Journal of Marketing 58(3): 53-66.

http://dx.doi.org/10.2307/1252310 
Anderson, E. W.; Mittal, V. 2000. Strengthening the satisfaction-profit chain, Journal of Service Research 3(2): 107-120. http://dx.doi.org/10.1177/109467050032001

Anderson, J. C.; Gerbing, D. W. 1988. Structural equation modeling in practice: a review and recommended two-step approach, Psychological Bulletin 103(3): 411-423.

http://dx.doi.org/10.1037/0033-2909.103.3.411

Babin, B. J.; Lee, Y.-K.; Kim, E.-J.; Griffin, M. 2005. Modeling consumer satisfaction and wordof-mouth: restaurants patronage in Korea, Journal of Services Marketing 19(3): 133-139.

http://dx.doi.org/10.1108/08876040510596803

Bitner, M. J.; Booms, B. H.; Tetrault, M. S. 1990. The service encounters: diagnosing favorable and unfavorable incidents, Journal of Marketing 54(1): 71-84. http://dx.doi.org/10.2307/1252174

Brady, M. K.; Cronin, J. J.; Brand, R. R. 2002. Performance-only measurement of service quality: a replication and extension, Journal of Business Research 55: 17-31.

http://dx.doi.org/10.1016/S0148-2963(00)00171-5

Brady, M. K.; Knight, G. A.; Cronin, J. J.; Tomas, G.; Hult, M.; Keillor, B. D. 2005. Removing the contextual lens: a multinational, multi-setting comparison of service evaluation models, Journal of Retailing 81(3): 215-230. http://dx.doi.org/10.1016/j.jretai.2005.07.005

Ciavolino, E.; Dahlgaard, J. J. 2007. ECSI-customer satisfaction modeling and analysis: a case study, Total Quality Management 18(5): S545-S554. http://dx.doi.org/10.1080/14783360701240337

Dabholkar, P. A.; Shepherd, C. D.; Thorpe, D. I. 2000. A comprehensive framework for service quality: an investigation of critical conceptual and measurement issues through a longitudinal study, Journal of Retailing 76(2): 139-197. http://dx.doi.org/10.1016/S0022-4359(00)00029-4

Ekinci, Y.; Dawes, P. L.; Massey, G. M. 2008. An extended model of the antecedents and consequences of consumer satisfaction for hospitality services, European Journal of Marketing 42(1/2): 35-68. http://dx.doi.org/10.1108/03090560810840907

Faullant, R.; Matzler, K.; Füller, J. 2008. The impact of satisfaction and image on loyalty: the case of Alpine ski resort, Managing Service Quality 18(2): 163-178.

http://dx.doi.org/10.1108/09604520810859210

Fornell, C. 1995. The quality of economic output: empirical generalizations about its distribution and relationship to market share, Marketing Science 14(3): G203-G211.

http://dx.doi.org/10.1287/mksc.14.3.G203

Fornell, C.; Johnson, M. D.; Anderson, E. W.; Cha. J.; Bryant, B. E. 1996. The American Customer Satisfaction Index: nature, purpose, and findings, Journal of Marketing 60(4): 7-18.

http://dx.doi.org/10.2307/1251898

Grönroos, C. 1984. A service marketing model and its marketing implications, European Journal of Marketing 18(4): 36-44. http://dx.doi.org/10.1108/EUM0000000004784

Heskett, J. L.; Sasser, W. E.; Schlesinger, L. A. 1997. The service profit chain. New York: Free Press.

Johnson, M. D.; Gustafsson, A.; Andreassen, T. W.; Lervik, L.; Cha, J. 2001. The evolution and future of national customer satisfaction index models, Journal of Economic Psychology 22(2): 217-245. http://dx.doi.org/10.1016/S0167-4870(01)00030-7

Jones, T. O.; Sasser, W. E. 1995. Why satisfied customers defect, Harvard Business Review 73(6): 88-99.

Konuk, F. A.; Konuk, F. 2013: The relationship between service quality economic and switching costs in retail banking, Business Systems Review 2(1): 1-16.

Kristensen, K.; Juhl, H. J.; Østergaard, P. 2001. Customer satisfaction: some results for European retailing, Total Quality Management 12(7\&8): S890-S897.

http://dx.doi.org/10.1080/09544120100000012 
Kristensen, K.; Martensen, A.; Grønholdt, L. 2000. Customer satisfaction measurement at Post Denmark: results of application of the European Customer Satisfaction Index methodology, Total Quality Management 11(7): S1007-S1015. http://dx.doi.org/10.1080/09544120050135533

Kumar, V.; Sharma, A.; Shah, R.; Rajan, B. 2013. Establishing profitable customer loyalty for multinational companies in the emerging economies a conceptual framework, Journal of International Marketing 21(1): 57-80. http://dx.doi.org/10.1509/jim.12.0107

Lee, H. S. 2013. Major moderators influencing the relationships of service quality, customer satisfaction and customer loyalty, Asian Social Science 9(2): 1-11.

Lehtinen, U.; Lehtinen, J. R. 1991. Two approaches to service quality dimensions, The Service Industries Journal 11(3): 287-303. http://dx.doi.org/10.1080/02642069100000047

Martensen, A.; Grønholdt, L.; Kristensen, K. 2000. The drivers of customer satisfaction and loyalty. Cross-industry findings from Denmark, Total Quality Management 11(4/5/6): S544-553.

Oliver, R. L. 1999. Whence consumer loyalty?, Journal of Marketing 63 (Special Issue): 3344. http://dx.doi.org/10.2307/1252099

Ostrom, A.; Iacobucci, D. 1995. Consumer trade-offs and the evaluation of services, Journal of Marketing 59(1): 17-28. http://dx.doi.org/10.2307/1252011

Rego, L. L. 1998. The relationship market structure-market efficiency from a customer satisfaction perspective, Advances in Consumer Research 25: 132-138.

Reicheld, F. F. 1995. The loyalty effect: the satisfaction trap: Essay No. 5. Boston, Bain \& Company.

Rust, R. T.; Zahorik, A. J.; Keiningham, T. L. 1995. Return on quality (ROQ): making service quality financially accountable, Journal of Marketing 59(2): 58-70. http://dx.doi.org/10.2307/1252073

Taylor, S. A.; Baker, T. L. 1994. An assessment of the relationship between service quality and customer satisfaction in the formation of consumer's purchase intentions, Journal of Retailing 70(2): 163-178. http://dx.doi.org/10.1016/0022-4359(94)90013-2

Türkyılmaz, A.; Özkan, C. 2007. Development of customer satisfaction index model. An application to the Turkish mobile phone sector, Industrial Management \& Data Systems 107(5): 672-687. http://dx.doi.org/10.1108/02635570710750426

Zeithaml, V. A. 2000. Service quality, profitability, and the economic worth of customers: what we know and what we need to learn, Journal of the Academy of Marketing Science 28(1): 67-85. http://dx.doi.org/10.1177/0092070300281007

Hana Šster ERJAVEC. PhD is an Assistant Professor at the Faculty of Business and Commercial Sciences. She received her Ph.D. in Economics from the University of Ljubljana. She teaches courses in marketing and methodological research at both undergraduate and graduate levels. Her main research interest is oriented toward customer satisfaction and customer loyalty. She is also a reviewer for articles in the field of marketing.

Tanja DMITROVIĆ. PhD is an Associate Professor of Marketing on the Faculty of Economics, University of Ljubljana. She received her Ph.D. in Economics from the University of Ljubljana. During her doctoral studies, she was a Hamilton fellow at the Massachusetts Institute of Technology in the US. Her current research interests include product nationality, customer relationship management, services research, and new product development.

Petra POVALEJ BRŽAN. PhD is a researcher at the Faculty of Electrical Engineering and Computer Science. She received her Ph.D. in Computer Science at the Faculty of Electrical Engineering and Computer Science, University of Maribor. She is an Assistant Professor and teaches courses in computer science, statistics, and research methodologies at different Faculties. Her current fields of interest include machine learning, data-mining, knowledge discovery, statistics, and health and medical informatics. 